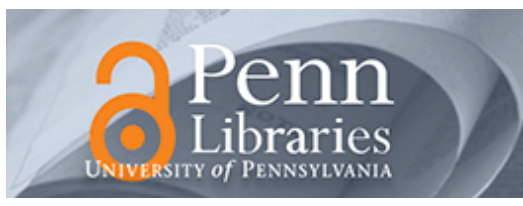

University of Pennsylvania ScholarlyCommons

Wharton Pension Research Council Working

Papers

Wharton Pension Research Council

$1-1-2010$

\title{
Collective Investments for Pension Saving: Lessons from Singapore's Central Provident Fund Scheme
}

Benedict SK Koh

Singapore Management University, skkoh@smu.edu.sg

Olivia S. Mitchell

The Wharton School, University of Pennsylvania, mitchelo@wharton.upenn.edu

Joelle HY Fong

The Wharton School, University of Pennsylvania, hfong@wharton.upenn.edu

Follow this and additional works at: https://repository.upenn.edu/prc_papers

Part of the Economics Commons

Koh, Benedict SK; Mitchell, Olivia S.; and Fong, Joelle HY, "Collective Investments for Pension Saving: Lessons from Singapore's Central Provident Fund Scheme" (2010). Wharton Pension Research Council Working Papers. 187.

https://repository.upenn.edu/prc_papers/187

This paper is posted at ScholarlyCommons. https://repository.upenn.edu/prc_papers/187

For more information, please contact repository@pobox.upenn.edu. 


\title{
Collective Investments for Pension Saving: Lessons from Singapore’s Central Provident Fund Scheme
}

\begin{abstract}
Singapore's mandatory national defined contribution pension system permits participants to invest their retirement savings in a wide range of investment instruments if they wish, rather than leaving their savings in $\mathrm{CPF}$ accounts to earn interest rate by default. This paper asks whether workers seeking to earn higher returns can expect to do better than the CPF-managed default, by moving their money into professionally-managed unit trusts. We use historical data to investigate whether fund managers possess superior stock-picking and market-timing skills, as well as whether they exhibit persistence in performance and offer diversification benefits to participants. The evidence is mixed, which could explain why so few participants opt out of the CPF-run default fund.
\end{abstract}

\section{Keywords}

Pension, retirement, investment, portfolio, investment choice, return and risk, trusts, managers, Singapore

\section{Disciplines}

Economics 


\title{
Collective Investments for Pension Saving: Lessons from Singapore's Central Provident Fund Scheme
}

\author{
Benedict S. Koh, Olivia S. Mitchell and Joelle HY. Fong
}

January 2010

\author{
PRC WP2010-01 \\ Pension Research Council Working Paper \\ Pension Research Council \\ The Wharton School, University of Pennsylvania \\ 3620 Locust Walk, 3000 SH-DH \\ Philadelphia, PA 19104-6302
}

Tel: 215.898.7620 Fax: 215.573.3418

Email: prc@wharton.upenn.edu

http://www.pensionresearchcouncil.org

\begin{abstract}
All opinions are solely those of the authors who acknowledge research support from the Wharton-SMU Research Center at Singapore Management University, and the Pension Research Council at The Wharton School of the University of Pennsylvania. Without implicating him, we acknowledge research assistance from Dimas Adrian Wijaya. Copyright 2010 (C) Pension Research Council of the Wharton School of the University of Pennsylvania. All rights reserved.
\end{abstract}




\title{
Collective Investments for Pension Saving: Lessons from Singapore's Central Provident Fund Scheme
}

\author{
Benedict S. Koh, Olivia S. Mitchell and Joelle HY. Fong
}

\begin{abstract}
Singapore's mandatory national defined contribution pension system permits participants to invest their retirement savings in a wide range of investment instruments if they wish, rather than leaving their savings in CPF accounts to earn interest rate by default. This paper asks whether workers seeking to earn higher returns can expect to do better than the CPF-managed default, by moving their money into professionally-managed unit trusts. We use historical data to investigate whether fund managers possess superior stock-picking and market-timing skills, as well as whether they exhibit persistence in performance and offer diversification benefits to participants. The evidence is mixed, which could explain why so few participants opt out of the CPF-run default fund.
\end{abstract}

Keywords: pension, retirement, investment, portfolio, investment choice, return and risk

\section{Benedict S. K. Koh}

Associate Professor of Finance

Singapore Management University

50 Stamford Road, \#04-01

Singapore 178899

T: 65-6828-0716 • F: 65-6828-0777

Email: skkoh@smu.edu.sg

\section{Olivia S. Mitchell}

International Professor of Employee Benefit Plans

Professor of Insurance and Risk Management

Director, Pension Research Council

Boettner Center for Pensions \& Retirement Research

The Wharton School, 3620 Locust Walk, St 3000 SHDH

Philadelphia, PA 19104-6320

T: 215-898-0424 • F: 215-898-0310

Email: mitchelo@wharton.upenn.edu

Joelle H.Y. Fong

Doctoral Student

Department of Insurance and Risk Management

The Wharton School, 3620 Locust Walk, St 3000 SHDH

Philadelphia, PA 19104-6320

Email: hfong@wharton.upenn.edu 


\title{
Collective Investments for Pension Saving: Lessons from Singapore's Central Provident Fund Scheme
}

\author{
Benedict S. Koh, Olivia S. Mitchell and Joelle HY. Fong
}

In a defined contribution (DC) system, participants bear the responsibility to amass sufficient wealth to finance their own retirement consumption. This paper explores how one of Asia’s foremost retirement programs, Singapore’s national mandatory Central Provident Fund (CPF) scheme, has approached investment choice for its participants in an effort to grow retirement wealth. Since 1986, the CPF has allowed savers to divert a portion of assets from their CPF accounts into individually-managed investment funds. Included in the list of permissible investment products are unit trusts (mutual funds) and investment-linked insurance products (ILPs) offered by private-sector professional fund managers. Prior research has shown that only 12 percent of investible funds, however, have been delegated to professional money managers (Koh et al. 2007) ${ }^{1}$. This paper asks whether the investment choices that workers could have selected as an alternative to leaving their savings in CPF accounts earning default interest rates do actually offer an advantageous instrument in growing employee savings. We also examine whether these funds help participants effectively diversify market risk.

This question is of interest for three reasons. First, a growing body of research has raised concern about how ready workers are to handle their own pension investment decisions, providing evidence of investment inertia, naive portfolio diversification, excessive reliance on conservative investment options, and financial illiteracy regarding basic investment concepts (Mitchell et al. 2007) ${ }^{2}$. This raises a question as to how much investment choice is actually beneficial in the context of retirement saving plans. Second, the recent investment record of participants that have used the CPF Investment Scheme (CPFIS) in Singapore has been 
discouraging. Whether this poor investment record might be due to the dismal performance of the financial markets or poor portfolio choice by individual participants, or both, is an empirical question. Third, in the last decade, CPF monies have been flowing rapidly out of CPF accounts into the unit trust industry. For example in 1997, CPF-included funds constituted just 16 percent (or $\$ 0.5$ billion) of the unit trust industry’s assets under management; by 2007, this had risen to 67 percent (or $\$ 26$ billion) ${ }^{3}$. Accordingly, a large and rising fraction of workers' retirement funds are in the hands of professional fund management companies, which makes it particularly important to investigate how they perform and whether they are effective in growing savings.

In what follows, we first survey the literature on the performance of professionallymanaged funds. Next, we briefly describe the structure of Singapore's CPF Investment Scheme and explain the role of unit trusts in the asset mix. This is followed by an analysis of the aggregate performance of unit trusts offered under the investment scheme for various holding periods. Subsequently, we investigate the return and risk profiles of the unit trusts and ascertain whether these funds seem to be well-positioned in conformity with their prospectuses. We also examine whether the unit trusts are sufficiently diversified and whether the fund managers exhibit superior stock selection and market timing skills. Last, we assess whether unit trusts show persistence in their performance.

\section{Prior Studies}

Most of the empirical literature on retail mutual fund manager performance has relied on U.S. data, where the broad consensus is that managers responsible for such funds tend to underperform their benchmark portfolios. Early studies on US mutual funds by Jensen (1968) and Sharpe (1966) ${ }^{4}$ showed that fund managers did not exhibit superior stock selection skills. 


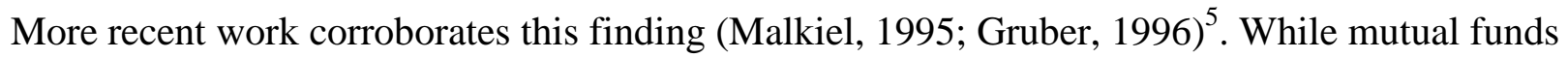
do not generate positive alphas, some analysts find evidence of persistence in mutual fund performance over shorter horizons of up to five years (Grinblatt and Titman 1992; Hendricks et al. 1993) $)^{6}$. Yet additional investigation by Malkiel (1995) noted that much of the evidence of persistency in performance was restricted to the 1970s and it disappeared in the 1980s. Carhart $(1997)^{7}$ further found that persistency in mutual fund performance can be explained by common factors in stock returns and investment expenses. In general, then, there is little convincing evidence of abnormal positive performance by U.S. professional fund managers.

Empirical evidence on U.S. fund manager market timing skills tends to be more mixed. For instance, some authors uncover no evidence of fund manager market timing skills, ${ }^{8}$ while others do offer support for timing skill in the average performance of mutual funds. ${ }^{9}$ Analysts who take into consideration the substantial evidence of non-stationary systematic risk levels in portfolios that consequently affect mutual fund performance tend to confirm the existence of significant timing in fund manager ability. ${ }^{10}$

In the Singapore context, Tse and Chia (1997) ${ }^{11}$ analyzed the performance of 36 equity unit trusts (including those outside of CPFIS) for 1990-99. The chosen funds concentrated their investment in stocks traded in Singapore and the Asian region. The authors concluded that fund managers performed poorly in security analysis and market timing, and they found no consistency in fund performance ranking. On the other hand, they showed that the unit trusts were well diversified and performed fairly well in terms of risk-adjusted returns, especially when compared to the risk-free rate. A more recent study by Chia, Chua and Tsui (2007) ${ }^{12}$ measured unit trusts' 1992-2006 performance using a sample of 87 unit trusts which represented about a third of the entire CPFIS-included universe of unit trusts (231). That study included only equity- 
based funds with a track record of more than 3 years, and the authors report mixed evidence of stock picking skills by fund managers and no evidence of market timing. They also confirmed that the performance of fund managers was not consistent over time.

The present paper develops a more comprehensive analysis of the risk-return characteristics of unit trusts included in the list of investment funds available to savers in the CPF (as of December 2007). We do so with the help of an exclusive dataset obtained from Morningstar Research Private Limited (“Morningstar”). ${ }^{13}$ Using this rich dataset, we evaluate the unit trust performance for a wider range of fund types than previous studies. Rather than concentrating exclusively on equity-based funds, here we review equity funds, balanced funds, and income funds in which CPF members might potentially invest, which provides a uniquely useful comparison of performance measures across major fund types in the unit trust industry. In so doing, we provide a comprehensive evaluation of all unit trusts included in the CPFIS list.

\section{The Central Provident Fund Investment Scheme}

The Central Provident Fund in Singapore was first established in 1955 as a mandatory savings program. ${ }^{14}$ Half a century later, the CPF has evolved into a wide-ranging social security system covering 3.2 million CPF members, of whom 1.58 million are active as of June $2008 .{ }^{15}$ Since its inception, the CPF has been a defined contribution plan financed by mandatory levies on employees' total monthly earnings up to an earnings cap. Contribution rates and caps have varied over time with current rates amounting to between 8.5 to 34.5 percent of salary depending on the employee’s age, and the monthly salary ceiling is set at $\$ \$ 4,500$ (approximately US\$3,333). ${ }^{16}$ 


\section{The Default CPF Fund}

When the Singaporean scheme was first established, the CPF Board requires members to leave their retirement savings in CPF accounts. These accounts pay a risk-free rate of return which as of mid-2008 was 2.5 and 4 percent respectively on CPF Ordinary Account balances (CPF-OA) and Special Account (CPF-SA) balances. The stipulated 2.5 percent is, in fact, a floor, since the actual interest rate is the higher of 2.5 percent or a "market-related interest rate" based on the weighted average of the 12-month fixed deposit rates (80\%) and the month-end saving rates (20\%) of the major local banks over the preceding 3 months. In this way, the Board guarantees a safe minimum nominal return, while offering participants the possibility of upside potential should market rates rise. From January 1, 2008 the CPF-SA rate is pegged to the 12-month average yield of the 10-year Singapore Government Security (10YSGS) plus 1\%. ${ }^{17}$

The CPF-OA and SA rates represent rather attractive risk-free rates of return, compared to the 'proxy risk-free rate' of about 0.25 percent (in May 2008) set by the Monetary Authority of Singapore. To help CPF members further improve returns on their retirement saving, the government has recently announced it will pay an additional bonus of 1 percent per annum on the first $\$ 60,000$ of a member’s combined OA and SA balances (as of June 2008). In addition, the interest rate for funds held in the Special Medisave Retirement Account (SMRA) is to be repegged to the 10-year Singapore Government Security (10YSGS) yield plus 1 percent. Had this new SMRA formula been in place since the first issue of 10Y SGS, the SMRA rate would have averaged 4.5 percent (MOM, 2008). The latter change may have an important impact on CPF members, since the attractive default rate of return combined with the 2.5 percent rate floor is likely to encourage members to leave their savings in CPF accounts and induce yet more inertia. On the other hand, if the floating SMRA rate ${ }^{18}$ were to fall, participants will need to be more 
nimble in deploying their SA balances out of their CPF accounts into alternative investment opportunities.

\section{General Structure of the CPFIS}

The CPF Investment Scheme has provided members with access to investment alternatives since 1986. Early on, CPFIS participants were permitted to invest only a portion of their OA and SA saving in the included set of instruments. However, from 2001, the portion was raised to 100 percent for both the OA and SA. ${ }^{19}$ Clearly, this provides participants much latitude and discretion in terms of creating and determining their own retirement asset portfolio ${ }^{20}$.

The range of products in which CPF members may invest their mandatory contributions is diverse. In 2008, for instance, CPF-OA funds could be invested in fixed deposits, Treasury bills, corporate bonds, property funds, equities traded on the Singapore stock exchange, bonds guaranteed by the Singapore government, annuities and endowments, ILPs, unit trusts, exchange traded funds (ETFs), fund management accounts, and gold. As CPF-SA balances are intended to be earmarked for old age, a slightly narrower set of investment products has been allowed for SA monies. It must be noted that the CPF Board does not endorse any product included on the CPFIS list though these instruments may be selected by members for investment.

With such a rich offering of investment options, it is of interest to examine whether CPFIS investors have been successful in growing their retirement saving. The recent evidence is not comforting: for instance, almost half of CPFIS Ordinary Account investors incurred investment losses in FY 2004-07, while one-third realized profits equal to or less than the default rate of 2.5 percent earned by those who left their saving in CPF accounts (see Table 1). Only one-fifth of the investors made net realized profits in excess of the OA interest rate. This poor 
investment performance has not gone unnoticed by policymakers, who point to high investment fees and expenses as one of the explanation for low returns ${ }^{21}$.

\section{Table 1 here}

\section{Growth of Unit Trusts under the CPFIS}

With such dismal investment performance, CPF members have progressively turned to professional fund managers to help manage their money, particularly unit trusts. A unit trust is similar to a US mutual fund, in that it is an investment vehicle which pools money from numerous investors to invest in a portfolio of securities such as shares, bonds, and deposits. Investors find unit trusts attractive because they offer them the benefits of diversification, liquidity as well as access to the services of professional fund managers.

Total assets held by Singapore-based money managers reached S\$1.2 trillion in 2007 (approximately US\$814 billion), of which S\$39 billion pertained to Collective Investment Schemes (CIS) which include equity funds, bond funds, balance funds, money market funds, and capital guaranteed/protected funds. There were a total of 349 of these CIS in 2007, of which 162 are included under the CPFIS. ${ }^{22}$ CPF-included CIS constituted only 18 percent of all CIS in 1997 , but by 2007, this jumped to 46 percent.

\section{Empirical Approach}

To investigate the performance of CPFIS included unit trusts, we rely on a time series of returns earned by funds with a track record of at least 10 years for two sample periods ending December 2001 and December 2007. These two end dates are specifically chosen to coincide with the bear and bull phases of the stock market cycle. In addition, we compare the performance of 
funds over five and 10 years, which we take to represent moderate and longer-term holding periods.

Our dataset was obtained from Morningstar Asia which provides monthly price observations at month-end for the Singaporean financial market. The observations utilize a reinvested income price series which assume that dividend distributions are reinvested. ${ }^{23}$ These fund returns are then compared to the individual funds' benchmark returns specified by the investment management companies as well as the three-month Treasury bill rate and the CPFOA rate (CPF default interest rate).

\section{Aggregate Performance of CPFIS Unit Trusts}

When unit trusts are sold by fund managers to the public, they often emphasize that such investments should be held over a relatively long investment horizon. This is because the performance of unit trusts fluctuates in tandem with the stock market and hence there is no guarantee that investors will not suffer losses in the short run. However, as fluctuations in asset prices tend to tamper off in the long run, investors can expect these funds to achieve positive capital appreciation over longer horizons.

To test this hypothesis, we compare the performance of unit trusts against three yardsticks: three-month T-bill rate, the CPF-OA rate, and the fund's own benchmark index return. The CPFOA rate is a sensible yardstick because an alternative to moving one’s CPF savings into the capital market directly would be to simply do nothing, leaving the money in the CPF OA account to earn the default return. Naturally, stock markets cycles mean that realized returns are volatile, but it is reasonable to expect unit trusts to outperform the risk-free rate as well as the CPF default interest rate in the long run. 
Table 2 provides summary statistics which show that Singapore’s unit trusts generally performed better over the long term than in the short term. Majority of unit trusts evaluated reported positive returns which are higher than the CPF default interest rate and the risk-free rate for most sample periods except for the 5-year holding period ending 12/01. The latter period coincided with the dotcom crash. Unlike hedge funds, unit trusts cannot exploit a market downturn by shortselling securities. Consequently, in a falling market, they can only mitigate their performance partially by underweighting stocks and overweighting bonds and deposits to minimize losses. Table 2 here

The average returns of CPFIS unit trusts range from $1.98 \%$ to $16.32 \%$ per annum for the five-year holding period, and from $7.96 \%$ to $10.27 \%$ per annum for the 10 -year holding period. Returns earned by these unit trusts are highly correlated with the performance of the stock market as a whole. For the period ending December 2001, returns were generally lower, coinciding with the dotcom crash. After 2002, the Singaporean stock market staged a recovery and unit trusts’ performance rose correspondingly. In particular, the $16.32 \%$ annualized average return earned by unit trusts for the five-year period ending December 2007 coincided with the worldwide stock market boom. While most unit trusts reported positive returns for all holding periods, a significant percentage of unit trusts underperformed the CPF default rate. Consistent with empirical studies from other countries, we also notice a high percentage of funds failing to beat their benchmarks in terms of average return. For instance, over the five-year holding period, only $39.5 \%$ earned more than their benchmarks, a statistic that rises to $64.6 \%$ for the 10 -year holding period. The performance of unit trusts is much better for the sample period ending December 2001, where 80-88 percent outperformed the benchmark indices. 


\section{Risk-Return Characteristics of Unit Trusts}

Investors select unit trusts based on the descriptions provided in fund prospectus, where UTs are broadly classified as equity, income, or balanced funds. Equity funds are expected to offer high return but at high risk since they invest in growth stocks with potential for capital appreciation but pay low dividend. By contrast, income funds are expected to offer low returns by assuming low risk. These funds invest in high quality bonds, money market instruments, and fixed deposits. Balanced funds are hybrids of growth and income funds, offering moderate capital growth and income at moderate risk.

While most funds declare their investment objectives clearly in their prospectus, it is not evident if their realized performance is congruent with the stated objectives. For example, an equity fund may report a low average realized return and low risk, or low average realized return at high risk. In such situations, the funds would be regarded as having failed to deliver on their promise. Accordingly, we seek to investigate whether CPFIS included unit trusts were able to position their funds appropriately as stated in the prospectus. We measure unit trusts' returns by average return and average excess return ${ }^{24}$, while their risks are measured by betas or standard deviations of returns.

Table 3 reports the return and risk profiles of 3 types of unit trusts. Our results show that during the 1/98 -12/07 bull market unit trust realized returns and risk were largely consistent with their prospectus profiles. For example, equity funds for the five-year investment horizon earned the highest average return (19.6 percent) followed by balanced funds (9.9 percent) and income funds (2.6 percent). While the equity fund returns were the highest, their risk assumed was also correspondingly the highest. The average standard deviation and beta of the equity funds was 13.6 percent and 0.89 respectively. These risk measures are higher than those of balanced funds (6.1 percent and 0.69) and income funds (3 percent and 0.31). The return and risk tradeoffs are also 
evident for the 10-year period, where equity funds reported the highest average return (11.2 percent) and highest risk (standard deviation of 23.4 percent and beta of 0.86) while income funds reported the lowest return (3.6 percent) and lowest risk (standard deviation of 2.6 percent and beta of 0.25). The positive relationship between return and risk appears to hold even for the bear market (1/9212/01), when equity and balance funds reported higher returns than income funds but they also bear higher risk. The only anomaly is the five-year horizon from 1/97-12/01 where equity and balanced funds reported dismal performance due to the dotcom crash.

Table 3 here

Figure 1 provides a sample plot of the realized return and risk profiles of the full sample of individual unit trusts for the five-year holding period. The plot shows that the risk-return profiles of individual funds were consistent with their stated objectives: that is, the income funds generally cluster in the lower left-hand quadrant of the graph, while equity funds cluster in the upper righthand quadrant. The average return and standard deviation of income funds are the lowest and hence these are often deemed most suitable for risk-averse investors such as older workers or retirees. Income funds allow these investors to protect their capital but at the cost of lower expected returns. By contrast, equity funds earned the highest returns but at high risk, so these are often deemed suitable for participants who can afford to take more investment risk in the hope of growing their saving.

Figure 1 here

\section{Risk Diversification}

One of the key benefits of investing in unit trusts is that they offer investors risk diversification which they might not otherwise be able to achieve on their own. Risk diversification occurs when 
investors spread their limited capital over a large number of stocks and financial assets. Financial analysts often measure risk diversification by the R-square statistic of regression of excess return of funds on the excess returns of the benchmark index. ${ }^{25}$

Panel A in Table 4 presents the R-square of equity and balanced funds for the five- and 10year holding periods. Income funds are excluded, as fund managers of such funds do not try to track the stock market benchmark indices. Our results show that equity and balanced funds in Singapore are relatively well diversified. The average R-square of equity funds range from 0.7 to 0.75 while those of balanced funds range from 0.64 to 0.82 . This means that over 64 percent of the variation in equity and balanced funds' returns is explained by movements in their benchmark indices. These results suggest that CPFIS unit trusts do help investors diversify their portfolio risk, a benefit particularly helpful for members with meager savings.

Table 4 here

\section{Stock Selection Skills}

Another benefit of investing in a unit trust is that investors can tap the expertise of professional fund managers to outperform the market. By relying on fund managers, CPF investors expect to earn higher risk-adjusted return than what they could achieve themselves. Investors expect professional fund managers to exhibit stock selection skills, that is, the ability to identify under-priced stocks for

inclusion in a portfolio. Analysts often use Jensen's alpha ${ }^{26}$ to gauge the stock selection skill of fund managers to earn superior returns. Fund managers with superior stock selection skills will report a positive alpha and those with inferior skills will report a negative one.

Panel B in Table 4 reports Jensen's alphas for equity and balanced funds for 5 and 10 year holding periods. The average alpha earned by equity funds ranges from 0.14 to 0.4 percent. Results 
are more mixed for balanced funds, which show a positive alpha in three holding periods and negative average alpha for the five-year holding period ending December 2007. While the average alpha of funds is positive, we test whether the funds' alphas are significantly different from zero at the $5 \%$ significance level. Our results show that the majority of funds do not report significant alphas. The percentage of equity fund managers with superior stock selection skills ranges only from 6 to 22.5 percent for the various sub-periods. For balanced funds, the proportion is much wider, ranging from 0 to 100 percent (the latter figure must be interpreted with care as there is only one balanced fund with a 10-year historical series ending December 2001).

Our overall observation is that the broad majority of unit trusts managers in Singapore do not exhibit superior stock selection skills. Accordingly, savers should not look to these fund managers to outperform market benchmarks.

\section{Market Timing Ability}

Besides stock selection, fund managers also resort to market timing to earn superior returns. In a bull market when stock prices are rising, a superior market timer would increase the risk exposure of his fund so that its value would rise much faster than the overall stock market. One strategy of achieving this is to increase the asset allocation in stocks and reduce holdings in fixed-income securities. Conversely in a bear market, the market timer would decrease the risk exposure of his fund so that the decline in its value would be less than the overall stock market. Under such a market condition, the fund manager can reduce his exposure to stocks but increase his holdings of fixed-income securities.

We follow Treynor and Mazuy (1966) to ascertain whether managers exhibit market timing skill by using the quadratic regression in equation (1). 


$$
\mathrm{R}_{\mathrm{jt}}-\mathrm{R}_{\mathrm{ft}}=\alpha_{\mathrm{j}}+\beta_{\mathrm{j}}\left(\mathrm{R}_{\mathrm{mt}}-\mathrm{R}_{\mathrm{ft}}\right)+\gamma_{\mathrm{j}}\left(\mathrm{R}_{\mathrm{mt}}-\mathrm{R}_{\mathrm{ft}}\right)^{2}+\varepsilon_{\mathrm{jt}}
$$

A positive gamma $\gamma_{j}$ indicates that the manager is able to time the market, increasing the weighting of risky securities in a market upturn and decreasing the weighting in a market downturn.

The results reported in Panel C of Table 9 show that the average gamma of equity and balanced funds cluster around 0 . The only exception is for balanced funds in the 5-year holding period ending $12 / 07$, where the average gamma was 0.97 . These results generally imply that equity fund managers do not exhibit market timing skills. Only 15 to 29 percent of equity funds report gammas larger than 0 at the five percent significance level. Most of the balanced funds also do not report positive gammas at the 5 percent significance level, except for the 10-year period ending 12/07. For this holding period, half of the funds have significant positive gammas. Accordingly, our conclusion is that fund managers generally do not exhibit market timing skills and so investors should not rely on fund managers to time their investments to earn abnormal returns.

\section{Unit Trusts’ Persistence of Performance}

Investors are always looking out for fund managers who are able to consistently outperform the market. Hence, they prefer unit trusts that have a consistently good track record. To measure the consistency of funds' performance, we compare the rankings of unit trusts across consecutive sample periods. We first compute Jensen's alpha of all unit trusts over a sub-period of 30 months and rank these funds in decreasing order based on their alphas. We repeat the process for the next, non-overlapping 30 month sub-period to generate another ranking. We then compute the Spearman's rank correlation coefficient ${ }^{27}(\rho)$ of these two pairs of rankings. Under the null 
hypothesis of no persistence in performance of unit trusts over time, the two sets of rankings will be uncorrelated and $\rho$ should be close to 0 .

The Spearman rank coefficients of unit trusts are reported in Table 5. They show very low correlation in funds' ranking over time. In addition, these correlation coefficients are generally not significantly different from zero which implies that the funds’ performance is not consistent across the two sub-periods. The only exception is the results for equity funds for the period ending 12/07. These results suggest that investors cannot rely on past performance of fund managers to predict their future performance.

Table 5 here

\section{Conclusion}

Singapore's pension system is coming under close scrutiny as it seeks ways to help members accumulate sufficient savings to finance their retirement years. One way to grow workers' savings is to have them invest in instruments that compound at high rates of return. Since 1986 when the CPF investment scheme was launched, the CPF Board has progressively expanded the menu of instruments that members may elect, though for those who took the challenge to invest themselves, the majority found it difficult to beat the CPF default interest rate and some have even lost money. Such dismal performance led some members to turn to professional fund managers to help them grow their savings.

We examine the performance of CPF-included unit trusts in Singapore to determine whether these were successful in helping investors enhance their retirement saving. Our results are mixed. On the positive side, unit trusts did provide members with substantial diversification benefits, which is especially helpful for small investors. We also find that fund managers 
positioned their funds appropriately in terms of return-risk tradeoffs as indicated in their prospectus. In addition, unit trusts provided average returns that were higher than the risk-free and the CPF default interest rates. On the negative side, only a minority of these funds outperformed their style-specific benchmarks. In particular, majority of the unit trust managers did not exhibit stock selection or market timing skills, even though investors might expect this from professional money managers. Our results also show that irrespective of whether they ran equity, income, or balanced funds, most fund managers found it difficult to turn in consistent performance over time. 


\section{References and Notes}

1. Koh, Benedict, Olivia S. Mitchell, Toto Tanuwidjaja, and Joelle Fong (2007). "Investment Patterns in Singapore’s CPF Central Provident Fund.” Journal of Pension Economics and Finance, March 7(1): 1-29.

2. Mitchell, Olivia S., Gary R. Mottola, Stephen P. Utkus and Takeshi Yamaguchi (2007). "The Dynamics of Lifecycle Investing in 401(k) Plans.” Pension Research Council Working Paper. The Wharton School, University of Pennsylvania.

3. See the 2007 Singapore Asset Management Industry Survey, a publication of Monetary Authority of Singapore. CPF-included funds do accept investments from non-CPF monies and hence the growth in the AUM of these funds may not be due entirely to the investment of CPF monies.

4. Jensen, M.C. (1968). “The Performance of Mutual Funds in the Period 1945-1964.” Journal of Finance, 23: 389416. Sharpe, W. (1966). "Mutual Fund Performance”. Journal of Business 39: 119-138.

5. Malkiel, Burton G. (1995). "Returns from Investing in Equity Mutual Funds 1971 to 1991.” Journal of Finance, 50: 549-572. Gruber, M.J. (1996). “Another Puzzle: The Growth in Actively-managed Mutual Funds.” The Journal of Finance, 51, No. 3: 783.

6. Grinblatt, M. and Titman, S. (1992). "Persistence in Mutual Fund Performance.” Journal of Finance, 47: 19771984. Hendricks, D., Patel, J. and Zeckhauser, R. (1993). "Hot Hands in Mutual Funds: Short Run Persistence of Relative Performance, 1974-1988.” Journal of Finance, 48: 93-130.

7. Carhart, M. (1997). “On Persistence in Mutual Fund Performance.” Journal of Finance, 52, 57-82.

8. Treynor J.L. and Mazuy K. (1966). "Can Mutual Funds Outguess the Market?” Harvard Business Review, 44: 131-136. Chang, E.C. and Lewellen, W.G. (1984). "Market timing and mutual fund investment performance." Journal of Business, Vol. 57: 57-72. Henriksson, R.D. (1984). "Market timing and mutual fund performance: an empirical investigation.” Journal of Business, Vol. 57: 73-96. Lehmann, B.N. and Modest, D.M. (1987). "Mutual fund performance evaluation: a comparison of benchmarks and benchmark comparisons." Journal of Finance, Vol. 42: 233-65. Cumby, R.E. and Glen, J.D. (1990). "Evaluating the performance of the international mutual funds.” Journal of Finance, Vol. 45: 497-521.

9. Wagner, J., Shellans, S. and Paul, R. (1992). "Market Timing Works where it Matters Most... In the Real World.” Journal of Portfolio Management, 18: 86-90. Brocanto, J. and Chandy, P. (1994). "Does Market Timing Really Work in the Real World?” Journal of Portfolio Management, 20: 39-44. Ferson, W.E. and Schadt, R.W. (1996). "Measuring Fund Strategy and Performance in Changing Economic Conditions." The Journal of Finance, Vol. 51, No. 2, June: 425-461.

10. Pfleiderer, P, and S. Bhattacharya (1983). “A Note on Performance Evaluation.” Technical Report No. 714, Stanford Univ., Graduate School of Business. Kon, S.J. and Jen, F.C. (1979). "The investment performance of mutual funds: an empirical investigation of timing, selectivity, and market efficiency.” Journal of Business, Vol. 52: 263-89. Miller, T.W. and Gressis, N. (1980). "Nonstationarity and evaluation of mutual fund performance." Journal of Financial and Quantitative Analysis, Vol. 15: 639-54.

11. Tse, Yiu Kuen and Chia, Joseph H.H. (1997). “An Empirical Analysis of Unit Trust Performance in Singapore.” Working Paper, Singapore Management University.

12. Chia, N.C., Chua, S. T. and Tsui, A. K. (2007). "The Central Provident Fund Investment Scheme in Singapore: A Preliminary Comparison of Returns.” Working Paper, National University of Singapore, Department of Economics, July.

13. Morningstar merged with Standard \& Poor’s Fund Services Asia in 2007. Standard \& Poor's Fund Services Asia has been appointed by the Funds Performance Tracking Committee, a committee chaired by and 
comprising of representatives from the Investment Management Association of Singapore (IMAS), the Life Insurance Association of Singapore, and the Securities Investors Association (Singapore), to monitor the performance of all unit trusts and ILPs included under the CPFIS. Standard \& Poor's Fund Services Asia monitors the performance of all unit trusts (UTs) and ILPs included in the CPFIS admissible set of investment options since mid-2002 (IMAS, various years).

14. Low, Linda and Aw T.C. (1997). Housing a Healthy, Educated, and Wealthy Nation through the CPF. The Institute of Policy Studies. Singapore: Times Academic Press. Low, Linda and T. C. Aw (2004). Social Insecurity in the New Millennium: The Central Provident Fund. Singapore: Times Academic Press.

15. Active CPF members are persons with at least one contribution in the current or preceding three months.

16. The exchange rate as of June 2008 was $\mathrm{S} \$ 1.35=\mathrm{US} \$ 1$.

17. Previously, the CPF-SA return is set at 1.5 percentage points above the CPF-OA rate.

18. Although the SMRA rate is floating, its volatility is tempered as it is adjusted only quarterly, and is based on averaging daily yields of the 10-year Singapore Government Securities benchmark over a period of one year. The CPF board will maintain a floor rate of 4\% from $1^{\text {st }}$ January 2008 to $31^{\text {st }}$ December 2009 to help members adjust to the floating SMRA rate.

19. After April 2008, CPF participants cannot invest the first $\$ 20,000$ in both their OA and SA accounts outside the CPF-managed pool, a restriction instituted because of the extra 1 percent interest to be paid on the first $\$ 60,000$ of a member's combined balances, with up to $\$ 20,000$ from the OA from 1 Jan 2008. This additional interest given by the CPF Board is meant to enhance retirement saving adequacy. Thus, the first \$20,000 restriction helps CPF members keep a basic amount of savings safe from investment risks. The threshold limit for SA accounts was raised to \$30,000 from 1 May 2009.

20. The CPF Board has imposed investment limits on certain asset classes such as stock and gold. For instance, members can only invest up to 35\% of their investible savings in shares, property funds and corporate bonds. These limits are in place so that members do not over-concentrate their portfolio in specific assets.

21. The other factors include poor investment timing and failure to diversify risk. For additional details, refer to speech by Singapore's Minister of Manpower in his speech (http://www.mom.gov.sg/publish/momportal/en/press_room/mom_speeches/2005/20050714speechbydmgenghenministerformanpowerand2ndministerford.html).

22. A CPF-included CIS may draw investments from one or more unit trusts under the CPFIS.

23. According to Morningstar (2007), all descriptions, formulae and examples utilize a Reinvested Income Price Series (RIPs) rather than the fund or indices pricing series. This is because RIPs are an aggregation of prices, income, splits and other corporate actions thus allowing fair and easy comparison between funds and indices.

24. A fund's excess return is computed as average return of fund less the Treasury bill's return.

25. The $R$ square or coefficient of determination of the regression $R_{j t}-R_{f t}=\alpha_{j}+\beta_{j}\left(R_{M t}-R_{f t}\right)+\varepsilon_{j t}$ measures the proportion of total variation of the fund's return that is explained by the variation of its benchmark's return; it ranges from 0 to 1.0 , and a fully diversified fund has an $\mathrm{R}^{2}$ of 1.0 .

26. Jensen's alpha is the intercept $\alpha_{j}$ in the excess return regression $R_{j t}-R_{f t}=\alpha_{j}+\beta_{j}\left(R_{M t}-R_{f t}\right)+\varepsilon_{j t}$.

27. The Spearman's rank coefficient is a non-parametric measure of correlation and is computed as shown: $\rho=1-\frac{6 \sum D_{i}^{2}}{N\left(N^{2}-1\right)}$ where $\mathrm{N}$ is the sample size and $\mathrm{D}_{\mathrm{i}}$ is the difference between the rankings of unit trust $\mathrm{i}$ over two different evaluation periods. 
Table 1: Net Realized Profits/Losses for Investments Held Under the CPF Investment Scheme Ordinary Account (CPFIS-OA):

\begin{tabular}{|c|c|c|c|c|c|}
\hline & 2007 & 2006 & 2005 & 2004 & 4-year \\
\hline $\begin{array}{l}\text { Members who made net realized } \\
\text { profits in excess of the OA interest } \\
\text { rate of } 2.5 \%\end{array}$ & 239,000 & 180,000 & 147,000 & 128,000 & \\
\hline$\%$ of Members & $28 \%$ & $23 \%$ & $19 \%$ & $17 \%$ & $22 \%$ \\
\hline $\begin{array}{l}\text { Members who made realized profits, } \\
\text { but equal to or less than OA rate }\end{array}$ & 245,000 & 257,000 & 250,000 & 240,000 & \\
\hline$\%$ of Members & $29 \%$ & $32 \%$ & $33 \%$ & $33 \%$ & $32 \%$ \\
\hline Members who made realized losses & 368,000 & 362,000 & 363,000 & 370,000 & \\
\hline$\%$ of Members & $43 \%$ & $45 \%$ & $48 \%$ & $50 \%$ & $47 \%$ \\
\hline
\end{tabular}

Note: Under the CPF Act, the Board pays a minimum interest of 2.5\% per annum. The interest rate for the Ordinary Account is $2.5 \%$ as at 30 Sep 2008. Source: Constructed from CPFIS Profits/Losses for the Financial Year ended 31 September 2005 \& 2007 www.cpf.gov.sg/cpf_info/ie/IE_reportpl.pdf (viewed on 20 July 2008)_mycpf.cpf.gov.sg/NR/rdonlyres/D324F161-1F6A-4699-A6BA-C5ACA0E11C5F/0/IE_reportpl.pdf (viewed on 20 July 2008) 
Table 2: Summary Statistics of CPFIS-included unit trusts

\begin{tabular}{|c|c|c|c|c|}
\hline \multirow{2}{*}{ Summary Statistics } & \multicolumn{2}{|c|}{ Period Ending Dec 2001} & \multicolumn{2}{|c|}{ Period Ending Dec 2007} \\
\hline & 5-year & 10-year & 5-year & 10-year \\
\hline Average Annual Return (\%) & 1.98 & 7.96 & 16.32 & 10.27 \\
\hline CPF OA (average) annual rate (\%) & 3.21 & 3.23 & 2.53 & 2.77 \\
\hline T-notes/bond Yield annual rate (\%) & 3.64 & 3.73 & 2.57 & 3.02 \\
\hline \multicolumn{5}{|l|}{ Proportion of funds with: } \\
\hline Average return $>0$ & $52.5 \%$ & $88.2 \%$ & $99.4 \%$ & $97.9 \%$ \\
\hline $\begin{array}{l}\text { Average return }>3 \text {-months' } \\
\text { T-bill rate }\end{array}$ & $30.0 \%$ & $82.4 \%$ & $93.6 \%$ & $85.4 \%$ \\
\hline Average return $>$ CPF rate & $32.5 \%$ & $82.4 \%$ & $94.4 \%$ & $85.4 \%$ \\
\hline Average return > Benchmark's return & $80.0 \%$ & $88.2 \%$ & $39.5 \%$ & $64.6 \%$ \\
\hline
\end{tabular}


Table 3: Return and risk profiles of CPFIS unit trusts

\begin{tabular}{|c|c|c|c|c|c|c|c|}
\hline \multirow[t]{2}{*}{$\begin{array}{l}\text { Holding } \\
\text { Period }\end{array}$} & \multirow[t]{2}{*}{ Average } & \multicolumn{3}{|c|}{ Period Ending Dec 2001} & \multicolumn{3}{|c|}{ Sample Period Ending Dec 2007} \\
\hline & & Equity & Balanced & Income & Equity & Balanced & Income \\
\hline \multirow{4}{*}{5 years } & Return (\%) & 2.13 & -1.21 & 5.82 & 19.60 & 9.90 & 2.60 \\
\hline & Excess return (\%) & -1.48 & -4.70 & 2.11 & 16.60 & 7.20 & 0.00 \\
\hline & Standard deviation (\%) & 28.64 & 22.04 & 4.18 & 13.60 & 6.10 & 3.00 \\
\hline & Beta & 0.87 & 1.03 & -0.01 & 0.89 & 0.69 & 0.31 \\
\hline \multirow{4}{*}{10 years } & Return (\%) & 8.07 & 9.26 & 6.51 & 11.20 & 7.70 & 3.60 \\
\hline & Excess return (\%) & 4.19 & 5.33 & 2.68 & 7.90 & 4.60 & 0.60 \\
\hline & Standard deviation (\%) & 22.96 & 25.08 & 4.50 & 23.40 & 15.90 & 2.60 \\
\hline & Beta & 0.88 & 0.78 & 0 & 0.86 & 0.96 & 0.25 \\
\hline
\end{tabular}

Source: Authors' computations

Table 4: R-square, Alphas and Gammas of CPFIS unit trusts

\begin{tabular}{|c|c|c|c|c|c|}
\hline \multicolumn{2}{|c|}{$\begin{array}{l}\text { Holding } \\
\text { Period } \quad \text { Average }\end{array}$} & \multicolumn{2}{|c|}{$\begin{array}{l}\text { Period Ending Dec } 2001 \\
\text { Equity } \\
\text { Balanced }\end{array}$} & \multicolumn{2}{|c|}{ Period Ending Dec 2007} \\
\hline \multicolumn{6}{|c|}{ Panel A: R-square of regression } \\
\hline $\begin{array}{l}5 \text { years } \\
10 \text { years }\end{array}$ & $\begin{array}{l}\text { R-square } \\
\text { R-square }\end{array}$ & $\begin{array}{l}0.70 \\
0.72\end{array}$ & $\begin{array}{l}0.67 \\
0.82\end{array}$ & $\begin{array}{l}0.75 \\
0.71\end{array}$ & $\begin{array}{l}0.64 \\
0.71\end{array}$ \\
\hline \multicolumn{6}{|c|}{ Panel B: Alpha of unit trusts } \\
\hline $\begin{array}{l}5 \text { years } \\
10 \text { years }\end{array}$ & $\begin{array}{l}\text { Average Alpha (\%) } \\
\% \text { where Alpha >0 } \\
\text { Average Alpha (\%) } \\
\% \text { where Alpha >0 }\end{array}$ & $\begin{array}{l}0.40 \\
6.00 \\
0.35 \\
14.00\end{array}$ & $\begin{array}{l}0.01 \\
0.00 \\
0.62 \\
100\end{array}$ & $\begin{array}{l}0.14 \\
15.00 \\
0.32 \\
22.50\end{array}$ & $\begin{array}{l}-0.02 \\
5.00 \\
0.07 \\
0.00\end{array}$ \\
\hline \multicolumn{6}{|c|}{ Panel C: Gamma of unit trusts } \\
\hline $\begin{array}{l}5 \text { years } \\
10 \text { years }\end{array}$ & $\begin{array}{l}\text { Average Gamma (\%) } \\
\% \text { where Gamma }>0 \\
\text { Average Gamma (\%) } \\
\% \text { where Gamma }>0\end{array}$ & $\begin{array}{l}0.00 \\
15 \\
0.00 \\
29\end{array}$ & $\begin{array}{l}0.01 \\
0 \\
0.00 \\
0\end{array}$ & $\begin{array}{l}-0.01 \\
20 \\
0.00 \\
27.5\end{array}$ & $\begin{array}{l}0.97 \\
5 \\
0.00 \\
50\end{array}$ \\
\hline
\end{tabular}

Source: Authors’ computations 
Table 5: Spearman Coefficients ( $\rho$ ) of CPF-included unit trusts ranking on the Jensen alpha measure

\begin{tabular}{l|ll|ll}
\hline \multirow{2}{*}{ Type of fund } & \multicolumn{2}{|l|}{ Period Ending Dec 2001 } & \multicolumn{2}{l}{ Period Ending Dec 2007 } \\
& \multicolumn{1}{|l}{ \# of funds } & $\boldsymbol{\rho}$ & \# of funds \\
\hline Equity & 0.17161 & 34 & $0.4634^{*}$ & 92 \\
Balanced & NA & 4 & 0.0281 & 19 \\
Income & NA & 2 & 0.0055 & 13 \\
\hline
\end{tabular}

Source: Authors' computations

* Significant at $5 \%$ level

@ Unreliable to compute statistical significance since the sample sizes are only 4 and 2 respectively for the balanced and income funds. 
Figure 1: Return and Risk Profile of Unit Trusts (5-year holding period)

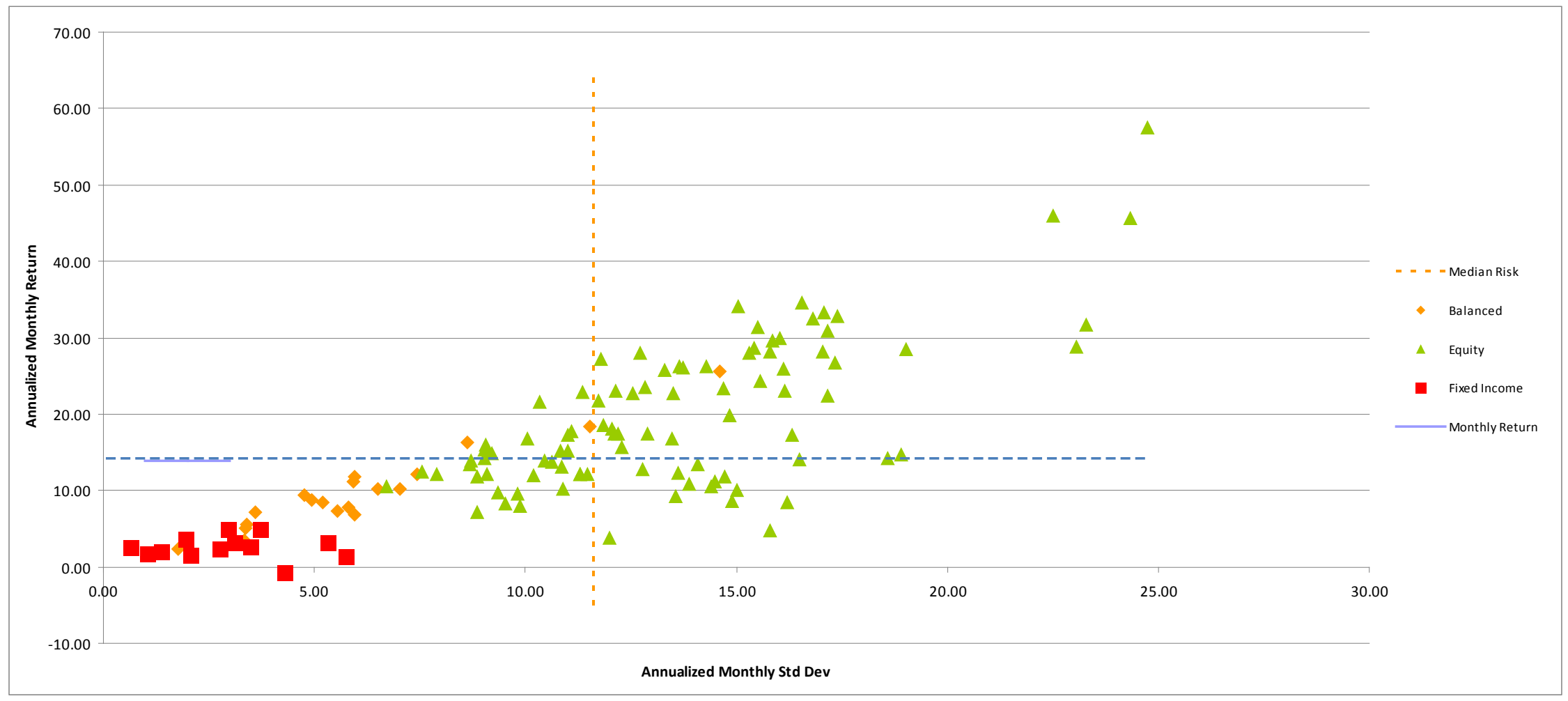

Source: Authors’ computations; see text 